\title{
Spider silk of Linothele fallax and Linothele megatheloides (Mygalomorphae, Dipluridae) does not affect the growth of bacteria
}

\author{
Paweł Szymkowiak $^{1}$ (D) $\cdot$ Maryia Tsiareshyna ${ }^{1} \cdot$ Ryszard Koczura $^{2}$ (i)
}

Received: 15 March 2019 / Accepted: 10 January 2020 / Published online: 16 January 2020

(C) The Author(s) 2020

\begin{abstract}
Due to physical and chemical properties as well as biocompatibility, spider silk has a great potential for use in medicine and biotechnology. It is applicable in the regeneration of the skin and nerve grafts. In this work, antibacterial property of spider silk was investigated. This feature would be especially useful for the application of spider threads in medicine. Silk of the spiders Linothele fallax (Mello-Leitão, 1926) and Linothele megatheloides Paz \& Raven, 1990 was tested on Escherichia coli, Pseudomonas aeruginosa, Staphylococcus aureus, and Enterococcus faecalis. Prior to inoculation, thesilk was weighed, sterilized with hydrogen peroxide and the effect of the silk on bacteria was tested in Mueller-Hinton broth. A lack of antibacterial properties of the silk of L. fallax and L. megatheloides was observed. The results on antimicrobial properties of silk of mygalomorph spiders are published for the first time.
\end{abstract}

Keywords Antibacterial property $\cdot$ Web $\cdot$ Mygalomorph spider

\section{Introduction}

The ability to produce silk is the most remarkable feature of spiders. Different types of silk produced by spiders are used by them in various ways, which also inspires peoples. In recent years, there has been an increase in the interest of researchers in this biomaterial and attempts to apply it in various areas of human life.

Spiders, depending on their needs, are able to produce several types of silk that differ in biochemical components and physical properties. There are several types of silk glands in Araneomorphae (mostly in orb-weavers): aggregate, cylindriform, flagelliform, aciniform, minor and major ampullate (Foelix 2011), and often a single gland type in Mygalomorphae (Palmer et al. 1982; Palmer 1985).

Paweł Szymkowiak

pawel.szymkowiak@amu.edu.pl

1 Department of Animal Taxonomy and Ecology, Faculty of Biology, Adam Mickiewicz University in Poznań, Uniwersytetu Poznańskiego 6, 61-614 Poznań, Poland

2 Department of Microbiology, Faculty of Biology, Adam Mickiewicz University in Poznań, Uniwersytetu Poznańskiego 6, 61-614 Poznań, Poland
Spiders use silk to secure their eggs, wrap the prey, store sperm, communicate, make shelter, and disperse (ballooning) (Żabka 2013).

Due to biocompatibility, strength and elasticity, spider silk has a great potential as a biomaterial. It is applicable in the regeneration of the skin (Wendt et al. 2011) and nerve grafts (Allmeling et al. 2006). Rypstra and Buddle (2012) suggested that silk can contribute to combating plant pests. Carbon nanotubes with silk showed improved electrical conductivity (Steven et al. 2013). In the future, spider webs can be used in the production of ropes, parachutes and biodegradable bottles as was suggested by Singha et al. (2012) and Babu (2013).

Information about antiseptic properties of spider silk has been mostly passed down by word of mouth from one generation to the next. The first written data can be found in the book Wunderbare Welt der Spinnen (Heimer 1988), in which the author suggested that microorganisms are not able to grow on spider silk because of its acidic character. He also stated that in the past humans had applied the tubular webs of Atypus Latreille, 1804 on wounds. Now it is known that spider silk has $\mathrm{pH}$ of 4 and contains high concentration of vitamin $\mathrm{K}$ which helps in blood coagulation (Wong et al. 2014). Despite historical usage of spider silk, there are few studies concerning its antibacterial properties. Borders (2001) examined the inhibition property of the spider silk on the growth of 


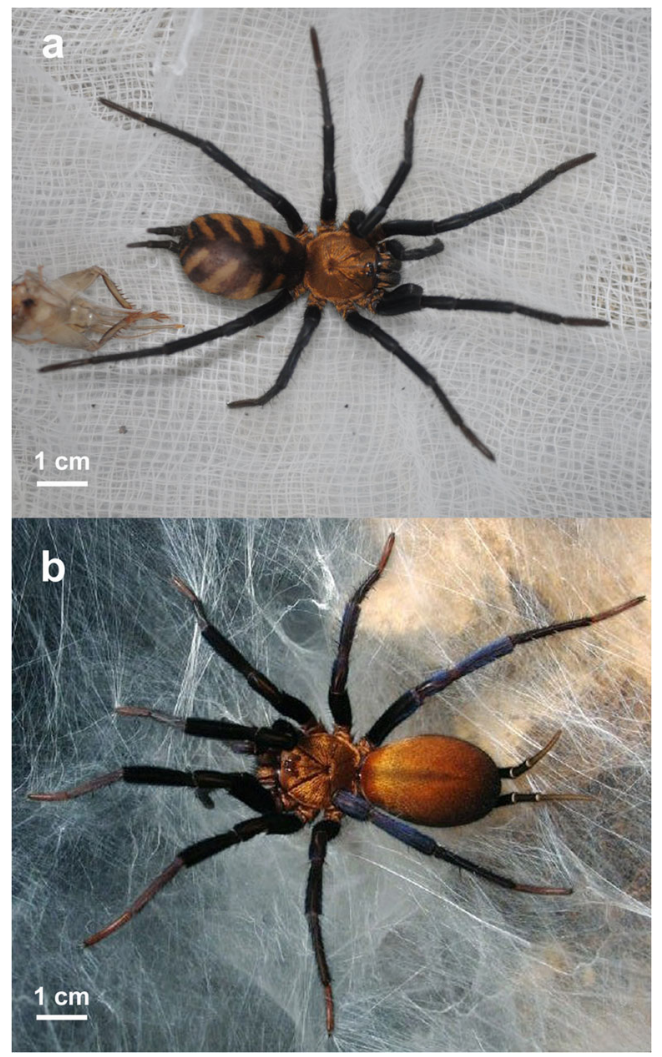

Fig. 1 Habitus of spiders, dorsal view: a female of Linothele fallax; $\mathbf{b}$ female of Linothele megatheloides. Photo by P. Szymkowiak (a), A. Małecka (b)
Gram-negative bacterium Pseudomonas fluorescens but stated that the results were inconclusive. Chakraborty and Das (2009) tested antibacterial property of proteins of pholcid web [(Crossopriza lyoni (Blackwall, 1867)] against Grampositive and Gram-negative bacteria and showed the antibacterial activity of the spider cob web proteins. Wright and Goodacre (2012) indicated that the silk of Tegenaria domestica (Clerck, 1757) significantly inhibited the growth of Escherichia coli, whereas the effect against Bacillus subtilis appeared to be short lived. In the same year, Mirghani and coauthors published the results of their studies on antibacterial properties of the silk of several spider species, extracted by using solvents such as methanol, ethanol, acetone and water (Mirghani et al. 2012). The acetone extract of silk showed the highest inhibition activity against $B$. subtilis and $E$. coli. Similar results were obtained by Roozbahani et al. (2014) and Al-Kalifawi and Kadem (2017) who used acetone as a solvent for silk of Pholcus phalangioides (Fuesslin, 1775) against Listeria monocytogenes and E. coli and silk of Tegenaria domestica against Enterobacter cloacae, E. coli, Klebsiella pneumonia, Streptococcus sp., B. subtilis, Pseudomonas aeruginosa, and Staphylococcus aureus.

Spider silk was also tested for its anti-fungal potential. This property of silk of orb-weaver spider, Neoscona theisi (Walckenaer, 1841), was evaluated by use of pieces of bread (Tahir et al. 2015). Although significant inhibitory effect of the web silk of $N$. theisi on fungi was noted, the results are not very reliable because the experiment was conducted in uncontrolled conditions. Except the abovementioned papers, other

Fig. 2 Posterior lateral spinnerets of Linothele megatheloides spinning threads of silk. Photo by A. Małecka

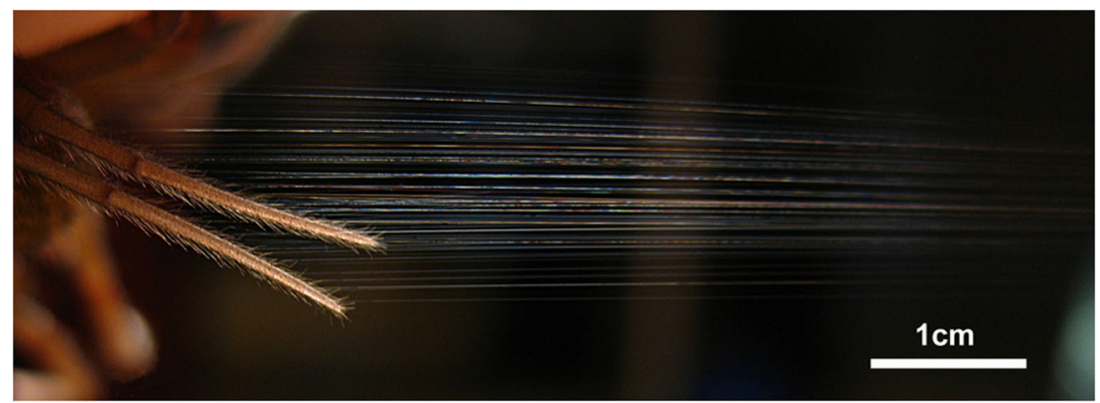

Table 1 The weight of spiders silk used for antibacterial property testing and days of breeding spiders after which the silk was collected

\begin{tabular}{|c|c|c|c|c|c|c|c|c|}
\hline & \multicolumn{4}{|c|}{ Linothele fallax } & \multicolumn{4}{|c|}{ Linothele megatheloides } \\
\hline & 1 & & 2 & & 3 & & 4 & \\
\hline Bacterial species & Weight & Days & Weight & Days & Weight & Days & Weight & Days \\
\hline Pseudomonas aeruginosa & 1.7 & 10 & 2.9 & 10 & 9.6 & 10 & 7.5 & 10 \\
\hline Escherichia coli & 12.8 & 14 & 13.6 & 14 & 13.9 & 14 & 8.1 & 14 \\
\hline Staphylococcus aureus & 36.9 & 14 & 4 & 14 & 5.3 & 14 & 9.4 & 14 \\
\hline Enterococcus faecalis & 37.3 & 14 & 4.7 & 14 & 6.4 & 14 & 11.3 & 14 \\
\hline
\end{tabular}

1-4: specimens of spiders 


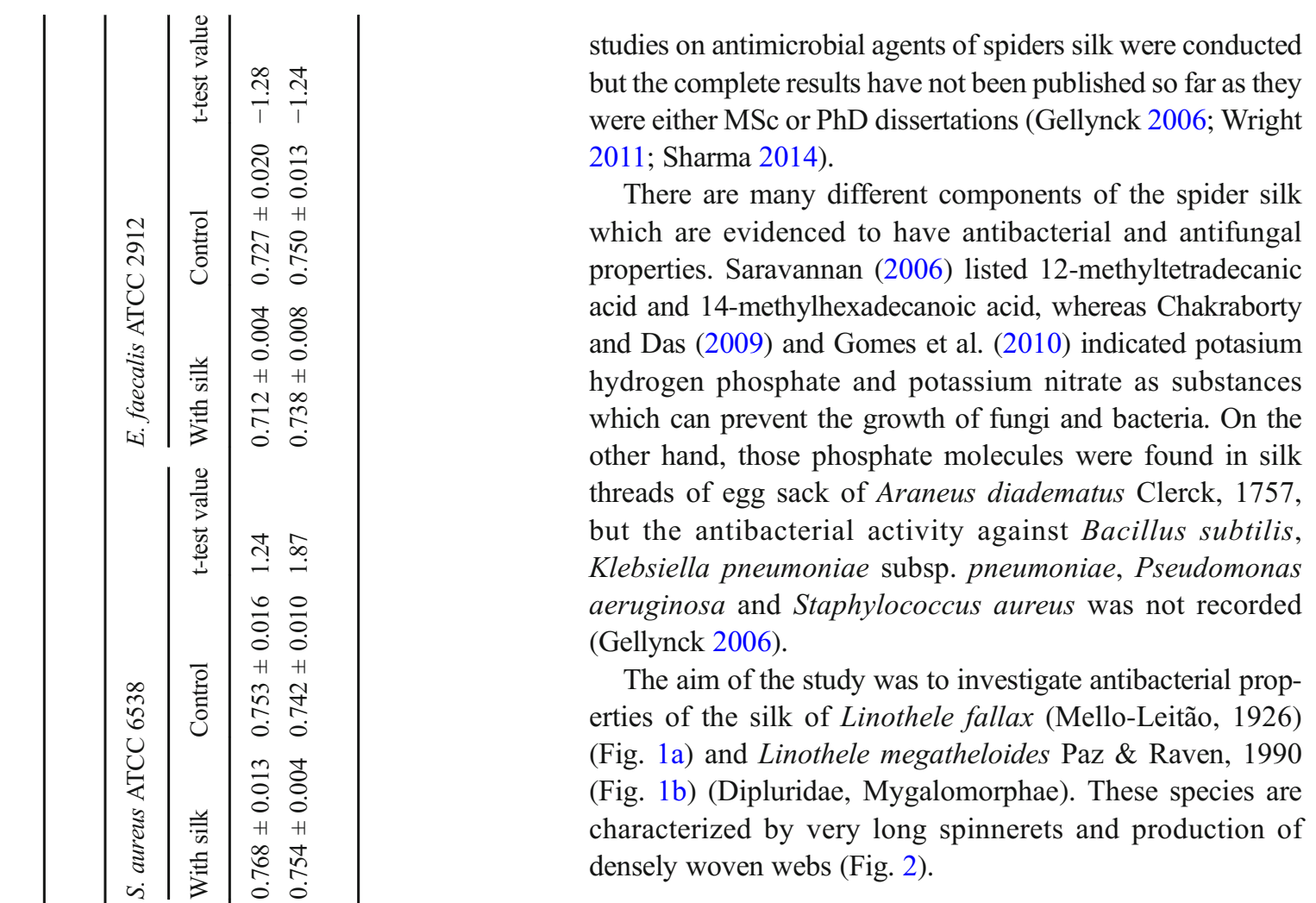

\section{Material and methods}

\section{Spider rearing}

Two specimens of $L$. fallax and two of $L$. megatheloides were bred in one-liter plastic containers with coconut chips. Breeding was started in the development stage of the subadult of both species. The substrate was covered with two layers of sterile gauze, which facilitated the removal of uncontaminated spider webs. It was sprayed with water every few days. Spiders were cultured at room temperature $\left(22-24^{\circ} \mathrm{C}\right)$ and fed with house cricket [(Acheta domesticus (Linnaeus, 1758)] every five to seven days. The spider web was collected to sterile containers every 10 to 15 days, compressed into a spherical shape and then weighed before each experiment (Table 1).

\section{Antibacterial property testing}

Antibacterial properties of the webs of L. fallax and L. megatheloides were tested against Gram-negative (Escherichia coli ATCC 8739 and Pseudomonas aeruginosa ATCC 9072) and Gram-positive (Staphylococcus aureus ATCC 6538 and Enterococcus faecalis ATCC 29212) bacteria. Spider silk (5-20 mg), sterilized with vapourized hydrogen peroxide, was added to $5 \mathrm{ml}$ of Mueller-Hinton Broth (Oxoid). The tubes were shaken for $1 \mathrm{~h}$ at $230 \mathrm{rpm}$ and then inoculated with approximately $5 \times 10^{5}$ bacterial cells. 
Incubation was carried out at $35^{\circ} \mathrm{C}$ for $18 \mathrm{~h}$. After incubation, the $\mathrm{OD}_{600}$ of cultures was measured by using Cary $3 \mathrm{E}$ spectrophotometer (Varian) and compared with positive control (bacterial culture without the silk). Normal distribution of the data was checked with Shapiro-Wilk test. The t-test was used to determine statistical significance of differences in $\mathrm{OD}_{600}$ values between bacterial cultures grown with and without (controls) silk. Statistical analysis was calculated with Statistica 13 (Statsoft).

\section{Results and discussion}

The $\mathrm{OD}_{600}$ values of bacterial cultures incubated with silk of L. fallax and L. megatheloides and the positive controls are presented in Table 2 . No significant decrease $(p>0.05)$ in the samples with silk added was observed for all bacterial species, regardless of the amount of the silk added and the spider species. The addition of silk to the medium did not inhibit the growth of E. coli, P. aeruginosa, S. aureus, and E. faecalis.

Previous studies that showed antiseptic properties of spider silk against Gram-positive, Gram-negative bacteria and fungi were carried out on silk of different species from the suborder Araneomorphae (Borders 2001; Chakraborty and Das 2009; Wright and Goodacre 2012; Roozbahani et al. 2014; Tahir et al. 2015). On the other hand, no data regarding antibacterial properties of silk of Mygalomorphae spiders have been published so far that [only unpublished data available in the PhD thesis of Wright 2011]. In our studies, we tested two of them, Linothele fallax and L. megatheloides. The silk of these species did not inhibit the growth of Gramnegative or Gram-positive bacteria. Similar results were obtained by Wright (2011), who tested the spider web of Lasiodora parahybana Mello-Leitao, 1917. In most cases, Mygalomorphae spiders capture prey through active attack and do not use silk to wrap it for immobilisation, later ingestion or storage (possible antimicrobial effect of silk protecting food against influence of bacteria and fungi) as orb-web weavers of Araneomorphae do (Eberhard 1967; Champion et al. 2001).

Nevertheless, a few studies indicated antiseptic properties of silk of spiders (Mirghani et al. 2012; Roozbahani et al. 2014; Al-Kalifawi and Kadem 2017); however, these results cannot be considered reliable because of the use of solvents such as methanol, ethanol and acetone which inhibit bacterial growth themselves (Tortora et al. 2013).

Antimicrobial properties of spider silk can also be influenced by spider diet and environmental conditions. Contamination of the spider silk by the ground had negative effect on its antibacterial properties (Wright 2011).

\section{Compliance with ethical standards}

Conflict of interest The authors declare that they have no conflict of interest.

Ethical statement All applicable international, national, and/or institutional guidelines for the care and use of animals were followed.

Open Access This article is licensed under a Creative Commons Attribution 4.0 International License, which permits use, sharing, adaptation, distribution and reproduction in any medium or format, as long as you give appropriate credit to the original author(s) and the source, provide a link to the Creative Commons licence, and indicate if changes were made. The images or other third party material in this article are included in the article's Creative Commons licence, unless indicated otherwise in a credit line to the material. If material is not included in the article's Creative Commons licence and your intended use is not permitted by statutory regulation or exceeds the permitted use, you will need to obtain permission directly from the copyright holder. To view a copy of this licence, visit http://creativecommons.org/licenses/by/4.0/.

\section{References}

Al-Kalifawi EJ, Kadem, YJ (2017) The antimicrobial activity of AlAnkabut's home (Spider's web) extract. In: Proceeding of 1st National Conference of Science and Art, University of Babylon, Mesopotemia Environmental Journal, Special Issue C, pp 54-63

Allmeling C, Jokuszies A, Reimers K, Kall S, Vogt PM (2006) Use of spider silk fibres as an innovative material in a biocompatible artificial nerve conduit. J Cell Mol Med 10(3):770-777. https://doi.org/ 10.1111/j.1582-4934.2006.tb00436.x

Babu KM (2013) Silk. Processing, properties and applications. Woodhead publishing, series in textiles 149. Oxford, Cambridge, Philadelphia, New Delhi

Borders WR (2001) An investigation of spider webs' antibacterial properties. Bulletin of the South Carolina Academy of Science, Columbia, S.C., Brief article. The Free Library. https://www. thefreelibrary.com/An+Investigation+of+Spider+Webs\%27+ Antibacterial+Properties.-a080159974. Accessed Jan 2019

Chakraborty D, Das S (2009) Antibacterial activities of cobweb protein. In: Proc 19th ECCMID (European Congress of Clinical Microbiology and Infectious Diseases), Helsikni, Finland, Abstract No. R2127

Champion CFE, Herberstein ME, Elgar MA (2001) Food caching in orbweb spiders (Araneae: Araneoidea). Naturwissenschaften 88:42-45. https://doi.org/10.1007/s001140000194

Eberhard W (1967) Attack behavior of diguetid spiders and the origin of prey wrapping in spiders. Psyche 74:173-181

Foelix RF (2011) Biology of spiders. Oxford University Press, New York

Gellynck K (2006) Silk and spider silk in tissue engineering. PhD dissertation, University of Ghent. https://biblio.ugent.be/publication/ 468009. Accessed 15 Jan 2019

Gomes S, Leonor IB, Mano JF, Reis RL, Kaplan DL (2010) Functionalized silk biomaterials for bone regeneration. In: Semana da Engenharia, Guimarães, 11-15 outubro 2010. Universidade do Mincho, Braga

Heimer S (1988) Wunderbare Welt der Spinnen. Urania-Verlag, Leipzig

Mirghani MES, Kabbashi NA, Elfaki FA, Fahmi MZ, Zulkifli B (2012) Investigation of the spider web for antibacterial activity. In: 
Malaysian International Conference on Trends in Bioprocess Engineering (MICOTriBE) BT-201, pp 1-5

Palmer JM (1985) The silk and silk production system of the funnel-web mygalomorph spider Euagrus (Araneae, Dipluridae). J Morphol 186:195-207

Palmer JM, Coyle FA, Harrison FW (1982) Structure and cytochemistry of the silk glands of the mygalomorph spider Antrodiaetus unicolor (Araneae, Antrodiaetidae). J Morphol 174:269-274

Roozbahani H, Asmar M, Ghaemi N, Issazadeh K (2014) Evaluation of antimicrobial activity of spider silk Pholcus phalangioides against two bacterial pathogens in food borne. Int $\mathbf{J}$ Adv Biol Biom Res 2(7):2197-2199

Rypstra AL, Buddle CM (2012) Spider silk reduces insect herbivory. Biol Lett 9:20120948. https://doi.org/10.1098/rsbl.2012.0948

Saravannan D (2006) Spider silk - structure, properties and spinning. J Text Appar Tech Manag 5(1):67-73

Sharma S (2014) Investigation of antimicrobial properties of spider silk. MSc dissertation, University of Akron. https://books.google.sk/ books/about/Investigation_of_Antimicrobial_Propertie.html?id= 1MN1rgEACAAJ\&redir esc $=$ y. Accessed Jan 2019

Singha K, Maity S, Singha M (2012) Spinning and applications of spider silk. Front Sci 2(5):92-100. https://doi.org/10.5923/j.fs.20120205. 02

Steven E, Saleh WR, Lebedev V, Acquah SF, Laukhin V, Alamo RG, Brooks JS (2013) Carbon nanotubes on a spider silk scaffold. Nat Commun 4:2435. https://doi.org/10.1038/ncomms3435
Tahir HM, Zaheer A, Yaqoob R (2015) Antifungal potential of silk recovered from Neoscona theisi (Araneae: Araneidae). Punjab Univ J Zool 30(2):81-83. https://doi.org/10.1038/ncomms3435

Tortora GJ, Funke BR, Case CL (2013) Microbiology: an introduction, 11 th edn. Pearson, Boston

Wendt H, Hillmer A, Reimers K, Kuhbier JW, Schäfer-Nolte F, Allmeling C, Kasper C, Vogt PM (2011) Artificial skin - culturing of different skin cell lines for generating an artificial skin substitute on crossweaved spider silk fibres. PLoS One 6(7):21833. https://doi.org/10. 1371/journal.pone.0021833

Wong J, Chan H-K, Chrzanowski W (2014) Silk for farmaceutical and cosmeceutial applications. In: Kundu SC (ed) Silk Biomatrials for tissue engineering and regenerative medicine, $1^{\text {st }}$ edn. Woodhead Publishing Series in Biomaterials, Amsterdam, pp 519-546

Wright S (2011) The antimicrobial properties of spider silk. MSc dissertation, University of Nottingham. http://eprints.nottingham.ac.uk/ 12033/1/Finalhandedinthesispdf.pdf. Accessed Jan 2019

Wright S, Goodacre SL (2012) Evidence for antimicrobial activity associated with common house spider silk. BMC Res Notes 5(326):1-6. https://doi.org/10.1186/1756-0500-5-326

Żabka M (2013) Pajęczy świat. Muzeum i Instytut Zoologii PAN, Warszawa

Publisher's note Springer Nature remains neutral with regard to jurisdictional claims in published maps and institutional affiliations. 